Running head: HOW UK CHARITIES USE FACEBOOK IN FUNDRAISING

\begin{abstract}
Using a multi-case study approach, this paper explores how the three biggest UK cancer charities by donations use Facebook in their fundraising campaigns, in order to facilitate understanding of the dynamics of philanthropic asking in a social networking site (SNS)mediated environment. The analysis reveals that Facebook is primarily used to strengthen relationships with supporters, mainly via humanising the brand, fostering obligations and encouraging social interaction. The mobilization of these relationships in fundraising is facilitated by persuasive strategies, including public recognition, authority and the fostering of a sense of efficacy among fans, and the most common outcome of this mobilization is public endorsement of charities' fundraising campaigns via sharing. At a time when harsh public spending cuts have left gaps in charity funding that need to be filled by philanthropy, this study aims to make a practical contribution to knowledge by examining what works and how in Facebook fundraising.
\end{abstract}

Key words: Organisational communication; non-profit organisations; new media; social networking sites; Facebook; online relationships. 


\section{Reinventing the rattling tin: How UK charities use Facebook in fundraising}

\section{Introduction}

There are only a handful of academic research studies examining how UK fundraisers ask for money, and none that focus specifically on how they do it via social networking sites (SNSs). This is remarkable, considering that a) social networking has been at the heart of fundraising for centuries (Owen, 1964; Shapely, 2000) and b) 92 per cent of UK charities use Facebook according to the latest published figures (NFP Synergy, 2011). Perhaps the paucity of literature in this area is due to the fact that, although most UK charities joined Facebook in 2008 , they have only recently started to use it strategically in fundraising, as suggested by the empirical findings of this study.

The scarcity of published academic work on the dynamics of charity fundraising in the UK does not detract from its significance as a research area, especially at a time when charities are losing vital government grants. A survey report by PwC, Charity Finance Group and the Institute of Fundraising (2013) argues that the tough economic climate is still putting UK charities under pressure, as increased demand for charity services is coupled with a reduction in public sector funding. According to NCVO (2015), charities lost more than $£ 3.8$ billion in government grants between 2003 and 2013, and, as austerity continues, there is little to suggest that this decline will be reversed.

It is in this climate of austerity that some practitioners are advocating the integration of online social networking in charities' fundraising strategies. The former head of the Strategy and Consumer Insight Department at Cancer Research UK, for example, argues that the rise of Web 2.0 is offering charities an opportunity to "re-visit traditional community fundraising approaches and adapt them to the online world" (Miller, 2009, p. 369). Miller is 
one of the social media experts interviewed for this study, and he is still adamant that social media in general and online social networking in particular can produce results for charities, if used correctly.

There is strong anecdotal evidence to support Miller's view. Comic Relief, for example, reportedly raised more than $£ 37$ million on Facebook and Twitter in 2011 (Taylor, 2011), while online games company Zynga used its Facebook games to generate $\$ 1.5$ million for the Haiti disaster in just five days (Whitson \& Dormann, 2011). More recently, the No Make-up Selfie campaign raised $£ 8$ million for Cancer Research UK in six days (Eccles, 2014), while the Ice Bucket Challenge meme increased Macmillan Cancer Support's fundraised income by a reported $£ 3$ million (Townsend, 2014).

However, SNS fundraising is still at its infancy, and few professionals in the sector understand why and how it works, while guidance from academic researchers has hitherto been scarce. By examining the dynamics of philanthropic asking on Facebook, this study aims to make a practical, as well as theoretical, contribution to knowledge.

\section{Literature review}

Most academic studies on fundraising in the UK focus on donor, rather than fundraiser, behaviour (see, for example, Skarmeas \& Shabbir, 2011; Sargeant, 2001; Bennett, 2003; and Cowley et al., 2011). Notable exceptions include Kay-Williams (2000), who explores fundraising as a process with an identifiable life-cycle, and Goatman and Lewis (2007), who examine the attitudes of UK charities in relation to website adoption and use. There is also a small body of work, mainly by marketing scholars and fundraising practitioners, examining different techniques of fundraising, from face-to-face (Jay, 2001) to direct marketing (Greenwood, 2002) and email (Lake, 1996).

To the best of this researcher's knowledge, there is currently only one published 
research study exploring the use of social networking sites by UK charities. This is a study by Quinton and Fennemore (2013), who use semi- structured interviews with charities and digital marketing agencies to investigate the use of online social networks in the UK charity sector. They claim that although UK charities are aware of the opportunities offered by social networking sites, they do not know how to take advantage of them fully.

Given the paucity of UK work in the area of social media fundraising, guidance was sought from international research, where evidence was found to suggest that SNSs are becoming an "incubator" for charity (McPherson, 2007, p. 35). Farrow and Yuan (2011), for example, establish a positive relationship between participation in alumni groups on Facebook and alumni's charitable giving behaviour; and Whitson and Dormann (2011), argue that the social interaction element of Facebook games makes them ideal vehicles for bringing about change in the offline world, including the reduction of poverty. The latter claim that micro-transactions in Facebook games are a successful way of fundraising, and offer a number of examples, including a partnership between social game developer Zynga with charity Save the Children to help victims of the 2011 Japan earthquake and tsunami.

US charities are certainly trying to harness the power of social media in their fundraising efforts. A study by Lovejoy and Saxton (2012) examines the use of Twitter by the 100 largest non-profits in the US by coding tweets according to their communicative function, and finds that 'action' (including fundraising) is the primary function of 15.6 per cent of all messages sent. According to Lovejoy and Saxton (2012, p. 345), "action" is "less about creating dialogue than it is about mobilizing resources and supporters to fulfill financial and strategic goals", which, they claim, "may be what many organizations ultimately want to achieve".

Despite the widespread excitement about the use of social media in the non-profit sector, there is some evidence that contradicts its value. A study by Nah and Saxton (2013, p. 
306), for example, examining the adoption and use of social media by US non-profit organisations, finds that fundraising is "negatively related to how frequently the organizations actually used social media...”. The researchers attempt to explain this result by suggesting that the more an organisation comes to depend on social media for its communication needs, the less it invests in more costly traditional fundraising activities, and this could impact on the total amount of revenue raised.

There is also evidence that some charities are sceptical about the value of social media in achieving results on the ground. Unicef Sweden, for example, recently issued a stark warning against slacktivism, arguing that Facebook 'likes' are not enough to pay for lifesaving polio vaccines for children (Khazan, 2013). This form of 'passive activism' on social media is useless, claim critics, unless it is accompanied by other, more meaningful activity (Moylan, 2013).

Clearly there is a need for more research into how charities can best use SNSs to maximise fundraising revenues. With more than 160,000 registered charities in the UK (Charity Commission, 2016) competing for increasingly dwindling resources, few can afford failed experiments with digital media.

This paper aims to shed light on the dynamics of Facebook fundraising in proposing the following research questions:

RQ 1: How are UK charities using Facebook in their fundraising efforts?

$R Q$ 2: What works and what is counterproductive in Facebook fundraising, and why?

\section{Method}

The main part of the fieldwork for this study took place from March to November 2014. A number of data collection and analysis methods, including focused interviews, webometrics and an online survey, were combined within a multi-case study approach that 
examined the use of Facebook fundraising by Cancer Research UK (CRUK), Macmillan Cancer Support and Marie Curie Cancer Care - the UK's three largest cancer charities by fundraised revenue (Rogers, 2012). The three cases were chosen because they shared enough similarities to suggest that similar results might be possible, which was important for replication.

\section{Webometrics}

Web content analysis was used to examine all the messages posted by the three cases on their Facebook pages from 1 March 2014 to 31 May 2014. A total of 370 posts were recorded in a table (copied and pasted from the original posts) and coded by a single researcher.

The classification scheme was informed by various studies in social media use (most notably Lovejoy \& Saxton, 2012; and Whiting \& Williams, 2013), social capital (including Bourdieu, 1986, Coleman, 1988, Resnick, 2001, Portes, 1998, and Nahapiet \& Ghoshal, 1998), online collective action (Kollock, 1999) and persuasion (including Cialdini, 2007, Flynn \& Lake, 2008, and Fogg, 2008). However, in the end, the codes were decided using an inductive process based on a review of Facebook posts from the three cases in January 2014.

The first stage of the web content analysis studied the content of the Facebook posts to determine their communicative functions, using as a starting point Lovejoy and Saxton's (2012) classification model of Information, Community and Action. Posts that delivered information from the charity to its fans in a one-way interaction were coded as 'Information'; posts that promoted interactive conversation with fans, and/or fostered the development of an online community were coded as 'Community'; while 'Action' was operationalized as posts that aim to persuade fans to engage in specific activity - donate, fundraise, share a post, buy a charity product, etc. - that will benefit the charities. 
In the second stage of the web content analysis, all 81 fundraising posts (categories 'donate' and 'fundraise') were copied onto a different table and ranked according to a shareability metric devised for this study as a way to assess the relative success of a Facebook post.

The shareability metric: Most of the social media experts interviewed as part of this research agreed that the significance of Facebook lies in the potential afforded to users to reach and influence friends of friends. In this sense, a post is successful if it has been shared by many fans, and the number of shares is clearly visible under each post. However, simply relying on the number of shares to compare posts would be highly problematic - a post could record a high number of shares simply because it reached more people than other posts and not because its content was more shareable. Ideally, it is necessary to divide the number of shares by the number of reached users for each post and multiply that by 100 to have a meaningful comparison marker. In the absence of fan reach figures, the study encountered a significant challenge, until one of the interviewees made the important point that 'sharing' a post is a step up the engagement ladder from 'liking' a post, which makes the ratio of shares to likes an acceptable visible marker of success.

By dividing the number of shares by the number of likes reported under each post and multiplying that number by 100 , a metric was produced that measured the shareability of each post. The higher that metric was, the more shareable, and therefore more successful, the post. Shareability metric $=$ number of shares $\div$ number of likes $\times 100$.

Combined with web content analysis, the shareability metric was a visible marker of success used to examine whether the top 30 most successful fundraising posts (the posts with the highest shareability metric) shared any common characteristics, including persuasion techniques like social proof, inspiration and public recognition, that were not prominent in the rest of the fundraising posts. 


\section{Survey}

Embedded within each case study was an online survey questionnaire comprising of 18 multiple choice, rating scale and demographic questions, which was designed to provide a numeric description of Facebook fan opinions and attitudes. The questions were informed by various studies in social media use (most notably Whiting and Williams, 2013; Kang et al., 2014) and persuasion (including Flynn and Lake, 2008; Fogg, 2008; Cialdini, 2007).

The population in the study was everyone who liked or shared a fundraising post by any of the three case studies over the period 1/3/2014 - 31/5/2014. Participants were recruited by posting requests for participation in the comment thread under each fundraising post analysed and on the charities' Facebook walls. Although non-random sampling is not the preferred method for social scientific surveys, as the sample may or may not be representative of the survey population, random sampling was not feasible in this case, as individual Facebook fans could not be contacted. A total of 155 Facebook users participated in the survey, and an overview of this sample is provided in table 1.

The fact that the sample was overwhelmingly female, and most of the participants were aged between 35 and 64, indicates that this was an appropriate sample given the population of interest. CRUK's senior social media manager, Aaron Eccles, confirmed during his interview that the charity's donors consist mainly of women over 35 (author's interview, 13 June 2014). JustGiving's social and labs product manager, Jonathan Waddingham, also stated that women are more likely than men to interact with fundraising posts. He claimed that more than $70 \%$ of the company's Facebook app users "who actually click on stuff" are women (author's interview, 4 August 2014).

Descriptive statistics were used to provide numeric descriptions of the attitudes of Facebook fans who interacted with charities' Facebook posts via liking or sharing (Creswell, 2003), and to determine any previous relationships with these charities. 


\section{Semi-structured Interviews}

Face-to-face interviews with senior members of the digital teams of the three cases provided insights into their SNS objectives and tactics, while similar interviews with social media consultants to these charities, the social and labs product manager at JustGiving and senior members of staff at smaller cancer charities provided an understanding of the context in which the three cases operated. The nine experts interviewed for this study, in the order in which they were interviewed (from May to November 2014), are listed in table 2.

All but one of the interviews were conducted face-to-face and audio recorded, while one was done via Facebook messaging at the request of the participant. The face-to-face interviews varied in length from 40 minutes to 1 hour 17 minutes, with the average being 54 minutes. Once the interviews were transcribed verbatim, copies were emailed to all participants for review and approval. All except one of the participants agreed to be named in any publications resulting from this study.

Thematic content analysis was then used to examine the transcripts. This involved "discovering themes in the interview transcripts and attempting to verify, confirm and qualify them by searching through the data and repeating the process to identify further themes and categories" (Burnard et al., 2008, p. 430). The qualitative data collected from the interviews complemented the quantitative data collected from the other two methods employed in this study. It both triangulated the quantitative data, and added depth and richness to the findings.

The data collected from all three methods were considered and common themes were identified (Simons, 2009). Themes that were identified consistently across the different data sets and triangulated were then incorporated into the findings.

\section{Findings and discussion}

The web content categorisation model of information-community-action proposed by 
Lovejoy and Saxton (2012) was a useful starting point in examining the content of charities' Facebook posts, and a number of conclusions were reached from the data collected using this model. For example, information was the single largest content category for all three cases in this study (encompassing 52\% of all 370 posts analysed), echoing Lovejoy and Saxton's (2012) finding that non-profit organisations use Twitter as an extension of their websites, and this result was corroborated by the interviews: "It's [Facebook is] something we want to always look at as a brand channel for us, so we want to be able to reach people first of all with our brand messages, with our stories, with our research news..." (Aaron Eccles, CRUK). The online survey found that information was important to the charities' Facebook fans. Asked what benefits they derived from participating in their chosen charity's Facebook community in a multiple choice question, $78 \%$ of the survey respondents chose the answer: 'The opportunity to obtain up-to-date information about the charity's work and/or issues that are important to me'.

However, although Lovejoy and Saxton (2012) claim that "Facebook statuses and tweets are so similar that many users, including several of the organizations in our study, send out the same messages on both outlets simultaneously", this study found that charities were aware of the fact that different social media platforms target different audiences, and tailored their messages accordingly. CRUK's Aaron Eccles, for example, explained that Facebook was the most obvious platform to reach the charity's traditional audience of women over 35, which is why it was more important to his team than Twitter (author's interview, 13 June 2014). The anonymous source from Charity $\mathrm{C}$ also indicated different institutional uses for Facebook and Twitter: "I think Facebook probably allows better quality of interaction with people - it's great for sharing photographs, it's great for getting albums up, it's great for having more in-depth conversations with people. I think people are more likely to share on Facebook, but Twitter is great for having a constant feed of information and calls to action 
going out on it" (author's interview, 16 June 2014).

Consequently, the Facebook posts examined in this research did not fit neatly into the categories originally designed by Lovejoy and Saxton (2012) to study Twitter posts, despite the authors' claims that they should. The majority of posts $(69 \%)$ analysed in this study actually had a tripartite communicative function, combining information with elements of community building and a call (or calls) to action. This finding suggests that a refinement of Lovejoy and Saxton's (2012) categorization scheme is needed to take into account the differences between different social media platforms.

\section{How UK charities use Facebook in their fundraising efforts}

Contrary to Lovejoy and Saxton, 2012, Waters et al., 2009, and Quinton and Fennemore, 2013, this study found that the three cases were taking advantage of Facebook's potential as a community-building tool, with 204 out of the 370 posts analysed containing some form of community-building. This finding was supported by the interviews, with the social media experts from all three cases emphasizing the importance of strengthening relationships with their fans. As Marie Curie Cancer Care’s Stuart Witts explained: “...we joined it [Facebook], and we still use it effectively, to keep in communication with our supporters and to strengthen that relationship over the long term”.

Building meaningful relationships with fans was a common aim of all three cases, as well as the smaller charities that participated in this research. However, contrary to the literature on online relationship development in public relations reviewed in this study, including Waters et al., 2009, and Brodie et al., 2001, the relationships with Facebook fans these charities sought to foster were ultimately a means to a financial end, as they all hoped that these relationships would eventually help them increase their fundraised revenue. None of the interview participants cited 'fundraising' as their primary objective in using Facebook, but they all indicated that they viewed it as a desirable final step on a journey that started with 
people liking their page. In between the first and final steps, fostering obligations, humanising their brand and encouraging social interaction all featured prominently on the agenda of the social media teams interviewed.

- “... if we've looked after and given great experiences to them to support them and their family member who's got cancer, they all donate to us" (Amanda Neylon, Macmillan Cancer Support).

- "I think it is about being ethical, being moral, being human; it's about building a longer term relationship with supporters and making sure that they see you as a charity which they can feel comfortable supporting and believing in" (Stuart Witts, Marie Curie Cancer Care).

- "...we wanted to have that one-to-one contact with supporters where we could have conversations... We want an engaged community that understands and loves our brand, and that wants to help" (Aaron Eccles, CRUK).

The interview findings were corroborated by the web content analysis, which found that obligations, identification and social interaction were the top three relationship-building techniques featured in the posts analysed: $44 \%$ of all posts fostered obligations (Coleman, 1988) by offering fans recognition, support or best wishes, thus obliging them to repay the kindness in the future; $31 \%$ of all posts reinforced identification (Nahapiet \& Ghoshal, 1998) with the charity by presenting the brand as a human being who shares a common language, vision and values with its supporters; and $20 \%$ of all posts promoted social interaction, or conscious exchange (Bourdieu, 1986), with supporters, both online, by inviting comments on Facebook, and offline, by inviting fans to interact with the charity in person or by telephone.

The results of the online survey conducted in this research show that the three cases were successful in maintaining strong relationships with fans, with $73 \%$ of respondents strongly agreeing with the statement "I like", 71\% strongly agreeing with "I trust", and 45\% strongly 
agreeing with "I share common values with" the charity whose fundraising posts they shared. Indeed, $44 \%$ of them strongly agreed with the statement "I owe gratitude to this charity".

Although all the interview participants agreed that Facebook was very important to their organisations, neither Marie Curie Cancer Care, nor Macmillan Cancer Support had any reliable return on investment (ROI) figures to justify their investment in social media, while CRUK declined to release their figures. Lack of social media ROI figures is a usual occurrence in the sector, according to Strategy Refresh founder Bryan Miller, as posting messages on Facebook is generally seen as a communications - rather than a fundraising activity. He argued: "Sadly, it is common and it largely goes back to the comms department stuff. It's that it's owned typically by the communications teams and communications teams rarely have an ROI as a KPI [key performance indicator] because they are not seen as an income generation department, whereas your fundraisers will always have ROIs (or should have)" (author's interview, 17 July 2014).

In addition, only a small proportion of the charities' Facebook posts called for donations (10\% of Macmillan Cancer Support posts, $7 \%$ of Cancer Research UK posts and 5\% of Marie Curie Cancer Care posts), supporting Lovejoy and Saxton's (2012) finding that non-profit organisations are missing the opportunity to use social media as mobilisational tools. The charities' social media experts confirmed this result in the interviews for this study, although they did indicate that fundraising was "growing in importance" (Aaron Eccles, CRUK) following the success of the No Make-up Selfie Campaign:

- 'I'm not convinced that there are a great deal of cases where money is directly coming through from a social channel... I think social is a great way of spreading the message about these donations, but not a great way of directly getting donations" (Stuart Witts, Marie Curie Cancer Care). 
- “...we do know that people who engage with us give us more money, but we didn't actually get them to give us money through Facebook [before the No Make-up Selfie Campaign]. So now we're starting to think of that kind of thing" (Amanda Neylon, Macmillan Cancer Support).

Only $29 \%$ of the online survey respondents replied 'Yes' to the question, 'Have you ever donated to a fundraising appeal by this charity directly via Facebook (i.e. by clicking a link on the charity's Facebook page)', and CRUK's Aaron Eccles confirmed that the donation tool on Facebook had proved unsuccessful: "We used to have one for a very long time, there was a donation tool there, but it wasn't linking properly and we weren't seeing that much traffic from people going straight through from Facebook to donate - when we looked into it, it wasn't the journey that people were taking" (author's interview, 13 June 2103).

JustGiving's Jonathan Waddingham (author's interview, 4 August 2014), was the only interview participant to provide evidence that Facebook could be monetised: "In the 12 months from start of July 2013 to end of June 2014 we had... \$100 million raised via Facebook". However, even he did not advise charities to use Facebook to ask for money directly from fans. He explained: "I think social [media] has got a really important role in donor stewardship and supporting journeys... So by sharing the impact of what a charity does on social media, you can help people understand not necessarily why they should give, but why they should feel good about the fact they've given beforehand". According to Waddingham, this type of content is very effective because it is the type of content that people want to share with their friends. "And that's ultimately the amazing benefit of social media: that you can reach the friends of the people you speak to".

Waddingham's view was supported by the results of the online survey. Asked in what ways, if any, being a Facebook fan of their chosen charity had changed their behaviour 
towards it, $67 \%$ of respondents said that it had made them "more likely to spread the word about this charity's work among my friends". This indicates that public endorsement via 'sharing' is the most common outcome of charities' investment in Facebook relationships with supporters. By comparison, 30\% indicated that being a Facebook fan of their chosen charity had persuaded them to 'engage in more fundraising activities in aid of' that charity; and $18 \%$ indicated that it had persuaded them 'to donate more to' that charity. Only $17 \%$ of respondents denied being influenced in any way to help their chosen charity increase its fundraised revenue, either directly or indirectly, by being a Facebook fan. Thus, even in the absence of ROI figures, this study has found evidence to suggest that the correct use of Facebook in fundraising can result in increased revenue.

\section{What works and what is counterproductive in Facebook fundraising}

Public recognition: This study has found that the monetisation of Facebook relationships with fans is facilitated by public recognition (offering supporters the chance to visibly show to their peers that they have done a good deed), with this persuasion technique being present in $37 \%$ of the top 30 most successful fundraising posts examined in stage 2 of the web content analysis, but in only $4 \%$ of the rest.

The No Make-up Selfie campaign, for example, asked supporters to share their photos on social media, thus signifying their monetary contribution to Cancer Research UK. Similarly, Marie Curie's Great Daffodil Appeal asked supporters to wear a daffodil (both in the offline world and on social media via a digital badge) to show their support.

In his discussion of motivations for contributing to digital public goods, Kollock (1999, p. 228) cites "the effect of contributions on one's reputation" and argues that "contributions will likely be increased to the degree that the contribution is visible to the community as a whole and to the extent there is some recognition of the person's contributions". Recognition is also cited as one of the social influence strategies used by 
Mass Interpersonal Persuasion (Fogg, 2008) - a form of persuasion made possible by Facebook that combines the strength of interpersonal persuasion with the reach of mass media.

Although nearly $70 \%$ of the online survey respondents disagreed or strongly disagreed with the statements: "I am more likely to like/share this charity's posts if it offers me a reward for liking/sharing", social credit is a strong currency with which charities can repay obligations to their supporters (Portes, 1998), and this was a strong theme in the interviews conducted for this study. Bryan Miller, for example, argued that social currency is "the main reason people do anything on social media" and explained: "People want to be seen among their peer group as individuals who are doing good things, and social media just makes that a bit easier" (author's interview, 17 July 2014).

Public recognition has been a motivating factor for charitable giving since before the advent of social media (Satow, 1975; Harbaugh, 1998), and this study has found that fundraising posts that include public recognition are more shareable and therefore more successful on Facebook.

Efficacy: Kollock (1999) cites a sense of efficacy (i.e. a sense of having an impact on one's group or community) as one of the motivations for contributing to the provision of digital public goods. For the purposes of this study, efficacy offers proof that supporters' actions have made a difference, and this persuasion technique was present in $23 \%$ of the top 30 most successful fundraising posts examined, but in only $8 \%$ of the rest. In the No Makeup Selfie campaign, for example, Cancer Research UK kept fans up to date with the total amount of money raised and reassured them that this money would save lives, while during its Great Daffodil Appeal, Marie Curie Cancer Care posted stories that demonstrated in a very emotive way how supporters' donations were having a real impact on the lives of people with terminal cancer. 
The importance of fostering a sense of efficacy in facilitating the mobilization of support via SNS communication is confirmed by the results of the online survey, where more than $90 \%$ of respondents indicated that they either agreed or strongly agreed with the statement: "I am more likely to like/share this charity's posts if I believe this action will make a difference".

A few of the social media experts interviewed for this study commented on the importance of using social media to show supporters the difference that their efforts were making in the real world. Stuart Witts, for example, stated that Marie Curie Cancer Care used Facebook to show supporters "where the money is being spent" (author's interview, 4 August 2014) while JustGiving's Jonathan Waddingham argued that charities should use social media to demonstrate the impact that their work has, thus boosting supporters' sense of efficacy and self-satisfaction. Both echoed findings from the literature review about the role of efficacy in online behaviour. In his discussion of motivations for providing public goods in an online environment, Kollock (1999, p. 228) argues: "If a sense of efficacy is what is motivating someone, then contributions are likely to be increased to the extent that people can observe changes in the community attributable to their actions". Fogg (2008) calls it "measured impact", but he evokes a similar concept when he argues that mass interpersonal persuasion is facilitated by people's ability to observe the effects of their efforts.

Authority: Authority is one of the principles of persuasion examined by Cialdini (2007), who argues that people are conditioned to obey experts and other figures of authority. For the purposes of this study, authority is personified by experts and celebrities, who set an example to follow. The web content analysis conducted in this research found that authority was a persuasion technique present in $33 \%$ of the top 30 most successful fundraising posts, but in only $16 \%$ of the rest. CRUK, for example, used a famous scientist to promote its No Make-up Selfie campaign, while Marie Curie Cancer Care used celebrities to endorse its Great 


\section{Daffodil Appeal.}

The above web content analysis finding was supported by the online survey, which found that more than $50 \%$ of respondents agreed or strongly agreed with the statement, "I am more likely to like/share this charity's posts if they are endorsed by an expert". By contrast, only $6 \%$ of the online survey respondents agreed or strongly agreed with the statement, "I am more likely to like/share this charity's posts if they are endorsed by a celebrity"- a finding that is at odds with the results of the web content analysis. One of CRUK's most successful posts featured Formula One driver Jenson Button promoting a charity triathlon, for example, while TV presenter Mel Giedroyc was successfully used to promote Marie Curie's Blooming Great Tea Party on 6 May 2014. Celebrity endorsement was also at the heart of both the No Make- up Selfie and Ice Bucket Challenge campaigns, yet Facebook fans overwhelmingly denied being influenced by it. It appears that fans are either reluctant to admit their reverence of celebrities, or they are unaware that they tend to share celebrity-endorsed posts. Cialdini (2007, p. 229) claims that people underestimate the effect of authority status on their behaviour: "Not only does it work forcefully on us, but it does so unexpectedly".

Inspiration: This study has found evidence that spurring supporters into action is facilitated by the use of inspiring stories and/or inspiring gestures. An emotive humaninterest story about how a young girl beat the odds to survive cancer thanks to research is inspiring, and so is a video of a woman and her surgical team dancing defiantly to Pharrell Williams' 'Happy' right before her breast cancer operation. Inspiration was present in $37 \%$ of the top 30 most successful fundraising posts, but in only $14 \%$ of the rest. The importance of inspirational posts was also strongly supported by the results of the online survey, where more than $78 \%$ of respondents agreed or strongly agreed with the statement, "I am more likely to like/share this charity's posts if they are inspirational".

Posting inspiring stories featuring people that fans could relate to on their Facebook pages 
was a very conscious decision by the charities. Amanda Neylon (Macmillan Cancer Support), for example, claimed: "Lots of people are doing lots of great stuff for us and we can't put everyone's great fundraising story on Facebook, but we try and make sure that we're highlighting someone every week..." (author's interview, 13 June 2014), while CRUK's Aaron Eccles confirmed that Facebook was a place where the charity aimed to share inspiring stories from both patients and researchers (author's interview, 13 June 2014).

Promise of fun and games: The association between charity and fun is a long and wellestablished one - Shapely (2000) argues that in the $19^{\text {th }}$ century this became part of the sector's constitution. Therefore, it is not surprising that a persuasion technique that has worked well for centuries in the offline world would also work well on Facebook - a channel used for entertainment and passing time (Hunt et al., 2012) and where members are most likely to share fun, 'boredom-busting' posts. The web content analysis for this thesis found that the promise of fun and games was present in $70 \%$ of the top 30 most successful fundraising posts, but in only $47 \%$ of the rest. Usually the promised fun was to be undertaken with friends. For example, Macmillan Cancer Support's most successful fundraising post invited fans to raise money for the charity by organizing a night of "booze, yummy food, and your best friends!" and one of CRUK's most successful fundraising posts urged fans to host a BBQ party for their friends. The web content analysis also found that $80 \%$ of the most successful fundraising posts had an upbeat tone, while the tone of the rest was neutral. Considering the fact that all three cases are cancer charities, the finding that not a single successful fundraising post alluded to suffering or despair is significant, and it is one that is supported by the online survey conducted in this study: $58 \%$ of respondents strongly agreed or agreed with the statement, "I am more likely to like/share this charity's posts if their tone is upbeat".

The interviews with the social media experts also highlighted the importance of 
making fundraising fun. JustGiving's Jonathan Waddingham (author's interview, 4 August 2014), for example, advised charities to try to make their fundraising events as exciting as possible: "I think it's about showing people how enjoyable that event is and being able to offer a unique experience. Sky dives have always been very popular, but now you get much more fun experiences, so instead of running 10k, for example, you have a colour run, where people run $10 \mathrm{k}$ but they dress in white and people throw colour pellets at them, so they come out at the end and they all look really cool and colourful".

Mobile text to donate codes: Although the web content analysis did not originally include a category for 'text to donate codes', they were present in six of the top ten most successful fundraising posts examined. They were mostly used by CRUK and Macmillan Cancer Support, with Marie Curie Cancer Care only using a mobile text to donate code twice during the three- month period of the web content analysis.

Mobile text to donate codes were seen by some of the social media experts interviewed for this study as one of the ingredients of the success of the No Make-up Selfie campaign. Kidscan's fundraising manager, Lowri Turner, said: “Text to donate campaigns have become massively popular" (author's interview, 14 May 2014), while Amanda Neylon admitted that the success of the No Make-up Selfie campaign had made Macmillan Cancer Support reconsider its use of text to donate codes. "We've always had these codes. But we didn't put them on Facebook and the 'no make-up selfie' campaign probably made someone think that we should" (author's interview, 13 June 2014). Shortly after the No Make-up Selfie campaign, mobile text to donate codes started to feature heavily on the Facebook pages of some charities, including that of Macmillan Cancer Support. Marie Curie Cancer Care took significantly longer to submit to the trend, but in the first four days of March 2015, the charity posted a total of seven fundraising messages with a mobile text to donate code, nearly two per day. 
The effectiveness of mobile text to donate codes stems from their simplicity and ease of use. Donors text a word to a mobile number and are charged a certain amount of money. They do not need to visit another webpage, or write a cheque - they can use a device that is ready to hand to make their contribution quickly and easily to their favourite charity, and this is very important, according to Jonathan Waddingham (author's interview, 4 August 2014). Asked what works on Facebook in the context of SNS fundraising, he said: "... I guess the technical thing is making it easy for supporters to fundraise for you." Indeed, it was by using technology to make it easier for people to support a cause that JustGiving became so successful, as Waddingham explained: “They didn’t have to handle any cash, we took care of all that, transacting the money, adding Gift Aid, and so it just made that process really easy for people".

Kollock (1999) and Resnick (2001) both argue that by reducing the cost of taking action, both in money and time, technology has a big behavioural effect on the exchange of resources, and this argument is supported by the findings of this study. Asked what the most common way of making their donations was, $45 \%$ of the online survey participants chose the answer: 'via a fundraising website like JustGiving, Virgin Money Givin, EverClick etc'. By comparison, only $6 \%$ of participants indicated that they donated by post and $11 \%$ by phone.

\section{Conclusion}

This study chose a case study approach to examine the use of Facebook in charity fundraising, focussing specifically on three big, national cancer charities. Given the lack of information on SNS fundraising, and the size of the gap in knowledge that required filling, this approach seemed ideal to generate rich data. However, although interviews with social media consultants to the charity sector and social media experts from other, smaller cancer charities set the context and provided valuable insights into how the sector as a whole uses 
online social networking, any statistical generalisation of the results would be unwise. This was a limitation that was anticipated from the beginning of the project, but a conscious decision was made to opt for breadth and detail of data at the expense of generalizability. Future studies might want to focus on just one aspect of SNS fundraising and design the research specifically to achieve external validity.

The researcher had originally hoped to gain access to information such as Facebook metrics and return on investment (ROI) figures from the three cases. However, the social media experts interviewed were very protective of their performance indicators and were reluctant to share this information. Some claimed that they did not have any ROI figures to share, while others declined to release them. Macmillan Cancer Support gave the amount of money raised in the No Make-Up Selfie campaign off the record. Since this study set out to assess the value of Facebook communication in the context of charity fundraising, being denied access to ROI figures and having no way of tracing donations back to Facebook meant that it had to rely on what people said they were giving and receiving, rather than what they actually did. This researcher is satisfied with the results achieved on the basis of this compromise, but a researcher with more privileged access would be able to produce results that are supported by hard figures, where available, which would add more credence to the findings.

Interestingly, this study found that the online survey participants overwhelmingly valued the opportunity to obtain up-to-date information (78\% of participants) more than the opportunity for social interaction (38\% of participants) in their participation in charities' Facebook communities. This finding was unexpected, as previous research into predictors of Facebook use found that information seeking was not a motive (Hunt et al., 2012). However, while Hunt et al. studied Facebook use among undergraduate students, there are no studies examining specifically the motives of people who connect with charities via Facebook. Such 
studies would both make a theoretical contribution to knowledge and help institutions post content that better meets their fans' expectations. 


\section{References}

Bennett, R. (2003). Factors underlying the inclination to donate to particular types of charities. International Journal of Nonprofit and Voluntary Sector Marketing, 8(1), 12 - 29.

Bourdieu, P. (1986). The forms of capital. In: Richardson, J. G. (Ed.), Handbook of Theory and Research for the Sociology of Education (pp. 241-258). New York: Greenwood.

Brodie, R. J., Ilic, A., Juric, B. \& Hollebbek, L. (2013). Consumer engagement in a virtual brand community: An exploratory analysis. Journal of Business Research, 66(1), 105- 114.

Burnard, P., Gill, P., Stewart, K., \& Treasure, E. (2008). Analysing and Presenting Qualitative Data. British Dental Journal, 204(8), 429 - 432.

Charity Commission (2016). Charities in England and Wales - 21 March 2016 [Online]. Retrieved from:

http://apps.charitycommission.gov.uk/showcharity/registerofcharities/SectorData/SectorOver view.aspx

Cialdini, R. B. (2007). Influence: The Psychology of Persuasion (rev. Ed.). New York: harpercollins Publishers.

Coleman, J. S. (1988). Social Capital in the Creation of Human Capital. The American Journal of Sociology, 94(1), S95 - S120.

Cowley, E., Mckenzie, T., Pharoah, C. \& Smith, S. (2011). The new state of donation: Three decades of household giving to charity 1978 - 2008 [Online]. Retrieved from: http:/www.cgap.org.uk/uploads/Presentations/SmithCowleyMcKenzie\%20Ne w\%20state\%20of\%20donation.pdf

Creswell, J.W. (2003). Research Design: Qualitative, Quantitative, and Mixed Methods Approaches ( $2^{\text {nd }}$ ed.). California: Sage Publications. 
Eccles, A. (2014, 25 March). How Cancer Research UK Raised £8million From a Campaign We Didn't Even Start. The Huffington Post [Online] Retrieved from:

http://www.huffingtonpost.co.uk

Erin, A. (2014, 12 March). Memejacking: How to Get Started Marketing with Memes [Weblog]. Retrieved from: http://shonaliburke.com/2014/03/12/memejacking-get-started-marketingmemes/

Farrow, H. \& Yuan, Y. C. (2011). Building Stronger Ties With Alumni Through Facebook to Increase Volunteerism and Charitable Giving. Journal of Computer-Mediated Communication, 16(3), $445-464$.

Flynn, F. F. \& Lake, V. K. B. (2008). Just Ask: Underestimating Compliance With Direct Requests for Help. Journal of Personality and Social Psychology, 95(1), 128-143.

Fogg, B. J. (2008). Mass Interpersonal Persuasion: An Early View of a New Phenomenon. In Oinas-Kukkonen, H., Hasle, P., Harjumaa, M., Segerståhl, K., and Øhrstrøm, P. (Eds.), Persuasive Technology, Third International Conference, PERSUASIVE 2008, Oulu, Finland, June 2008, Proceedings (pp. 23-34). Berlin: Springer.

Goatman, A.K. \& Lewis, B. R. (2007). Charity E-volution? An evaluation of the attitudes of UK charities towards website adoption and use. International Journal of Nonprofit and Voluntary Sector Marketing, 12(1), 33-46.

Gorsky, M. (1999). Patterns of Philanthropy: Charity and Society in Nineteenth-Century Bristol. Suffolk: The Boydell Press.

Greenwood, C. (2002). Direct marketing in the UK for charities. International Journal of Nonprofit and Voluntary Sector Marketing, 7(3), 213- 218.

Harbaugh, W.T. (1998). The Prestige Motive for Making Charitable Transfers. The American Economic Review, 88(2), 277-282.

Hart, K. \& Greenwell, M. (2009, 22 April). To Nonprofits Seeking Cash, Facebook App Isn't So 
Green. The Washington Post [Online]. Retrieved from: http://washingtonpost.com

Hunt, D., Atkin, D. \& Krishnan, A. (2012). The Influence of Computer- Mediated

Communication Apprehension on Motives for Facebook Use. Journal of Broadcasting \& Electronic Media, 56(2), 187-202.

Internetworldstats.com (2014). Internet Usage Statistics: World Internet Users and 2014

Population Stats [Online]. Retrieved from: http://www.internetworldstats.com/stats.htm

Jay, E. (2001). The rise - and fall? - of face-to-face fundraising in the United Kingdom. New

Directions for Philanthropic Fundraising, 33(1), 83 - 94.

Jamieson, D. (2000). Relationship building in the networked age: Some implications of the Internet for non-profit organizations. Philanthropist, 15(2), 23-32.

Kang, J., Tang, L. \& Fiore, A. M. (2014). Enhancing consumer-brand relationships on restaurant Facebook fan pages: Maximizing consumer benefits and increasing active participation. International Journal of Hospitality Management, 36(1), 145-155.

Kay-Williams, S. (2000). The five stages of fundraising: A framework for the development of fundraising. International Journal of Nonprofit and Voluntary Sector Marketing, 5(3), 220240.

Khazan, O. (2013, 30 April). UNICEF Tells Slacktivists: Give Money, Not Facebook Likes. The Atlantic [Online]. Retrieved from: http://www.theatlantic.com

Klein, K. (2011). Fundraising for social change. $6^{\text {th }}$ ed. San Francisco, CA: Jossey-Bass.

Kollock, P. (1999). The economies of online co-operation: gifts and public goods in cyberspace. In: Smith, M. And Kollock, P. (Eds.), Communities in Cyberspace (pp.: 219-240). London: Routledge.

Lake, H. (1996). Electronic mail as a fundraising tool. Journal of Nonprofit and Voluntary Sector Marketing, 1(4), 360 - 365.

Lovejoy, K. \& Saxton, G. D. (2012). Information, Community, and Action: How Nonprofit 
Organizations Use Social Media. Journal of Computer-Mediated Communication, 17(3), $337-353$.

Mcpherson, R. C. (2007). Digital Giving: How Technology is Changing Charity. New York: iUniverse, Inc.

Miller, B. (2009). Community fundraising 2.0 - the future of fundraising in a networked society? International Journal of Nonprofit and Voluntary Sector Marketing, 14(4), 365-370.

Moylan, B. (2013, 27 March). The Red Marriage Equality Sign on Your Facebook Profile is Completely Useless. Vice [Online]. Retrieved from https://www.vice.com

Nah, S. \& Saxton, G. D. (2013). Modeling the adoption and use of social media by nonprofit organizations. New Media Society, 15(2), 294-313.

Nahapiet, J. \& Ghoshal, S. (1998). Social Capital, Intellectual Capital, and the Organizational Advantage. The Academy of Management Review, 23(2), 242-266.

NCVO (2015). UK Civil Society Almanac 2015: Income From Government. [Online]. Retrieved from https://data.ncvo.org.uk/a/almanac15/government/

NFP Synergy (2011). Social Media League Table [Online]. Retrieved from: http://nfpsynergy.net/social-media-league-table

Owen, D. (1964). English Philanthropy: 1660 - 1960. Cambridge, MA: The Belknap Press of Harvard University Press.

Quinton, S. \& Fennemore, P. (2013). Missing a strategic marketing trick? The use of online social networks by UK charities. International Journal of Nonprofit and Voluntary Sector Marketing, 18(1), 36-51.

Resnick, P. (2001). Beyond bowling together: Sociotechnical capital. In: Carroll, J. M. (Ed.), Human-Computer Interaction in the New Millennium (pp. 247-272). New York: AddisonWesley Professional. 
Rogers, S. (2012, 24 April). Britain's top 1,000 charities ranked by donations. Who raises the most money? The Guardian. Retrieved from http://www.theguardian.com

Sargeant, A. (2001). Relationship Fundraising: How to Keep Donors Loyal. Nonprofit Management \& Leadership, 12(2), 177-192.

Satow, K. L. (1975). Social approval and helping. Journal of Experimental Social Psychology, 11(6), 501-509.

Simons, H. (2009). Case Study Research in Practice. London: Sage Publications Ltd.

Shapely, P. (2000). Charity and Power in Victorian Manchester. Manchester: Smith Settle on behalf of The Chetham Society.

Skarmeas, D. \& Shabbir, H. A. (2011). Relationship quality and giving behaviour in the UK fundraising sector; Exploring the antecedent roles of religiosity and self-construal. European Journal of Marketing, 45(5), 720-738.

Spencer, T. (2002). The Potential of the Internet for Non-Profit Organizations. First Monday, 7(8) [Online]. Retrieved from: http://firstmonday.org

Portes, A. (1998). Social Capital: Its Origins and Applications in Modern Sociology. Annual Review of Sociology, 24(1), 1-24.

PWC, Charity Finance Group \& The Institute of Fundraising (2013). Managing in the 'new normal' - adapting to uncertainty [Online]. Retrieved from: http://www.institute-offundraising.org.uk/library/managing-in-a-downturn/

Shapely, P. (2000). Charity and Power in Victorian Manchester. Manchester: Smith Settle on behalf of The Chetham Society.

Taylor, R. (2011, 29 March). How Comic Relief has benefited from social media. [Weblog]. Retrieved from: http://www.redcmarketing.net/blog/online-marketing/how-comic-relief-hasbenefited-from-social-media/ 
Townsend, L. (2014, 2 Sept.). How much has the ice bucket challenge achieved? BBC News Magazine [Online]. Retrieved from: http://www.bbc.co.uk/news/magazine-29013707

Waters, R. D., Burnett, E., Lamm, A. \& Lucas, J. (2009). Engaging stakeholders through social networking: How nonprofit organizations are using Facebook. Public Relations Review, $35(2), 102-106$.

Whiting, A. \& Williams, D. (2013). Why people use social media: a uses and gratifications approach. Qualitative Market Research: An International Journal, 16(4), 362-369.

Whitson, J. R. \& Dormann, C. (2011). Social gaming for change: Facebook unleashed. First Monday, 16(10) [Online]. Retrieved from: http://www.firstmonday.org 
Table 1: Demographic characteristics of the online survey respondents

\begin{tabular}{|c|c|}
\hline Demographic characteristics & Percentage \\
\hline \multicolumn{2}{|l|}{ Gender $(n=152)$} \\
\hline Female participants & $95.39 \%$ \\
\hline Male participants & $4.61 \%$ \\
\hline \multicolumn{2}{|l|}{ Age $(n=154)$} \\
\hline $18-24$ & $7.79 \%$ \\
\hline $25-34$ & $13.64 \%$ \\
\hline $35-44$ & $24.03 \%$ \\
\hline $45-54$ & $28.57 \%$ \\
\hline $55-64$ & $21.43 \%$ \\
\hline $65+$ & $4.55 \%$ \\
\hline \multicolumn{2}{|l|}{ Place of residence $(n=149)$} \\
\hline North of England & $22.15 \%$ \\
\hline Midlands & $18.12 \%$ \\
\hline South of England & $36.24 \%$ \\
\hline Wales & $8.72 \%$ \\
\hline Scotland & $11.41 \%$ \\
\hline Outside the UK & $3.36 \%$ \\
\hline \multicolumn{2}{|l|}{ Number of Facebook friends $(n=152)$} \\
\hline Less than 10 & $0 \%$ \\
\hline $11-100$ & $34.87 \%$ \\
\hline $101-200$ & $29.61 \%$ \\
\hline $201-300$ & $15.79 \%$ \\
\hline $301-400$ & $6.58 \%$ \\
\hline $400+$ & $13.16 \%$ \\
\hline \multicolumn{2}{|c|}{ Frequency of checking Facebook news feed $(\mathrm{n}=154)$} \\
\hline Every day & $81.82 \%$ \\
\hline Most days & $16.23 \%$ \\
\hline At least once a week (on average) & $1.30 \%$ \\
\hline At least once a month (on average) & $0.65 \%$ \\
\hline Occasionally & $0 \%$ \\
\hline Not at all & $0 \%$ \\
\hline
\end{tabular}


Table 2: The interview sample

\begin{tabular}{|c|c|c|c|}
\hline Participant name & Organisation & Job title & $\begin{array}{l}\text { Date of } \\
\text { interview }\end{array}$ \\
\hline Lowri Turner & Kidscan & $\begin{array}{l}\text { Fundraising } \\
\text { Manager }\end{array}$ & $14 / 5 / 2014$ \\
\hline Aaron Eccles & $\begin{array}{l}\text { Cancer Research } \\
\text { UK }\end{array}$ & $\begin{array}{l}\text { Senior Social } \\
\text { Media } \\
\text { Manager }\end{array}$ & $13 / 6 / 2014$ \\
\hline Amanda Neylon & $\begin{array}{l}\text { Macmillan Cancer } \\
\text { Support }\end{array}$ & $\begin{array}{l}\text { Head of } \\
\text { Digital }\end{array}$ & $13 / 6 / 2014$ \\
\hline Anonymous & $\begin{array}{l}\text { Anonymous cancer } \\
\text { charity in North } \\
\text { West England } \\
\text { (Charity C) }\end{array}$ & $\begin{array}{l}\text { Social Media } \\
\text { Officer }\end{array}$ & $18 / 6 / 2014$ \\
\hline $\begin{array}{l}\text { Fiona Jade } \\
\text { Cunningham }\end{array}$ & $\begin{array}{l}\text { 'No Makeup Selfie } \\
\text { for Cancer } \\
\text { Awareness' } \\
\text { Facebook page }\end{array}$ & Founder & $16 / 7 / 2014$ \\
\hline Bryan Miller & Strategy Refresh & Founder & $17 / 7 / 2014$ \\
\hline Stuart Witts & $\begin{array}{l}\text { Marie Curie Cancer } \\
\text { Care }\end{array}$ & $\begin{array}{l}\text { Social media } \\
\text { and online } \\
\text { community } \\
\text { manager }\end{array}$ & $4 / 8 / 2014$ \\
\hline $\begin{array}{l}\text { Jonathan } \\
\text { Waddingham }\end{array}$ & JustGiving & $\begin{array}{l}\text { Social \& labs } \\
\text { product } \\
\text { manager }\end{array}$ & $4 / 8 / 2014$ \\
\hline Bertie Bosrédon & Self-employed & $\begin{array}{l}\text { Digital } \\
\text { consultant for } \\
\text { the not-for- } \\
\text { profit sector }\end{array}$ & $4 / 11 / 2014$ \\
\hline
\end{tabular}

